\title{
Disposal Management Practices of Unserviceable Electronic Resources
}

\author{
Joselito Tangaran $^{1)}$, Donald M. Patimo ${ }^{1 *}$, Rodolfo F. Dollado ${ }^{1)}$ \\ 1) Northwest Samar State University \\ *Corresponding Author: donald.patimo@nwssu.edu.ph
}

\begin{tabular}{llll} 
Article history & & \\
\hline Received & Received in revised form & Accepted & Available online \\
01 October 2020 & 29 January 2021 & 31 March 2021 & 31 March 2021 \\
\hline
\end{tabular}

\begin{abstract}
Establishment and household-generated electronic wastes are becoming a significant problem. Literatures showed that the volume of electronic wastes generated worldwide is increasing, thus becoming a threat to the environment and human health. In the local setting, Calbayog City is experiencing the same dilemma on electronic waste. This problem prompted the researchers to conduct this study. This study aimed to assess the disposal management practices of unserviceable electronic resources as observed in Calbayog city and identify the problems encountered in the disposal management of electronic wastes resources. The questionnaire was used as the primary research instrument to gather data. The respondents of the study were households and establishments in Calbayog city. In addition to the questionnaire, the researchers conducted an interview, inventory and actual site visit to the landfill area. The overall results of the study showed that TV sets were the most common electronic wastes generated in the city $(\mathrm{f}=193)$; and lack of disposal facilities for ewastes as most-felt problem encountered in the disposal of electronic waste resources $(\mathrm{f}=184)$. The result implies that repair of electronic waste, especially TV sets, is widely practiced by the community to lessen the problem on the disposal of electronic resources.
\end{abstract}

Keyword: Disposal, Disposal Management, Electronic Resources, Waste Management,

\section{Introduction}

The modern technology has been one of the leading drivers of change in an economy over the last few decades, has contributed significantly, and has become part of everyone's life. Every day, people encounter this modern technology at home, school, at work wherein this technology is being used to better the way people live by providing comfort, security, and even contribute to peoples' health. Modern technology has launched people at a time of convenience and instant gratification. With a flick of a switch, people can light up the darkness, connect with the world, or travel anywhere in the world in a matter of hours. Humans are becoming more and more reliant on machines to do simple activities [1].

The same technology that has made lives better is on the downside creating more toxic problems for the society. With the growth of IT and related industries, the usage and disposal of electrical and electronic equipment are all set to increase, which will increase the quantity of

Vol. 6 No. $1,8-12$ electrical and electronic waste generated. The waste generated refers to the various forms of electric and electronic equipment that have reached the end of their life or the machine that are no longer of any use to their owners. The waste contains both valuable materials as well as hazardous materials that require special handling and recycling methods. E-waste includes ever-growing the range of obsolete electronic devices such as computers, servers, TVs and others [2]. According to Yale Environment 360, 50 million tons of e-waste was generated worldwide, about 15 pounds for every person on the planet. This volume of electronic waste generated worldwide is expected to climb by 33 percent every year [3]. The Integrated Waste Management Board considered e-waste best management practices for the most environmentally desirable method of disposal. This means to handle e-waste with no contamination to the environment. If these kinds of wastes are mishandled, toxic substances may pollute water or air and may lead to severe illness or disease in animals and humans [4].

Electric and electronic waste resources are chemically and physically different from other

http://dx.doi.org/10.22135/sje.2021.6.1.8-12 
forms of municipal or industrial waste. Many useful materials may be recovered and reused from the electronic scraps that need recycling methods. However, there are also hazardous materials that require handling methods to avoid environmental contamination and detrimental effects on human health. The wastes that come under this category are varied. Electronic gadgets contain components made of toxic chemicals and metals such as lead, cadmium, chromium, mercury, beryllium, antimony, brominated flame-retardants, polyvinyl chlorides (PVC), and phthalates. Long-term exposure to these substances damages the physiological systems such as nervous systems, reproductive and endocrine systems. Some of them are carcinogenic and neurotoxic [5]. Over the years, electric and electronic resources that were acquired will reach to their end of operational life or become outdated; people will continuously obtain new models to replace outdated and unserviceable resources to suit their operational needs. Projections of additional million units will become obsolete, and more than a million units go into landfill and storage every year.

In the local setting, Calbayog City is experiencing the same dilemma on electronic waste. Based on the pre-survey conducted there were an estimated 0.5005 tons of electronic wastes generated for a month. According to Peralta [6] approximately 25 million units will be come obsolete and additional 14 million units are projected to become obsolete in the 5 years.

The above data shows an alarming volume of electronic wastes which needs action. Thus, the development and implementation of efficient system disposal are imperative. With this problem, the researchers conceptualized this study which aimed to investigate the disposal practices and the problems encountered in disposal practices of unserviceable electronic wastes in Calbayog City.

\section{Materials and Methods}

This study applied the descriptive research design. The respondents of the study were grouped into two, namely households and establishments. The selection of the respondents from the household group and establishment group were purposively selected based on the criteria that they have unserviceable electronic resources. The selection was considered regardless of the economic status and the type of business of the respondents. The researchers surveyed an actual number of eighty-nine (89) establishments and one hundred four (104) households in the Calbayog City proper. The electronic waste identified in the study include the following: CD/DVD, Radio, TV, Boards, Chargers, Mouse, Telephones, Calculators, Digital Cameras, Motherboards, MP3 Players, Laptops, Transformers, Electric Fans, Tablets, Headsets, Circuit Breakers. The electronic wastes were identified through an actual observation and collection of actual electronic wastes disposed in the landfill. Garbage collectors in the landfill area were tapped to collect disposed electronic wastes for the duration of three months. The researchers prepared a letter asking permission for a survey. The researchers presented these letters to the respondents with the attached questionnaire. During the distribution of the questionnaires, the researchers explained the purpose of the survey as well as the manner of accomplishing the questionnaire. The data collected were tallied and analyzed using statistical tools to come up with interpretations of the results of the study. Figure 1 shows the research process flowchart in conducting the study.

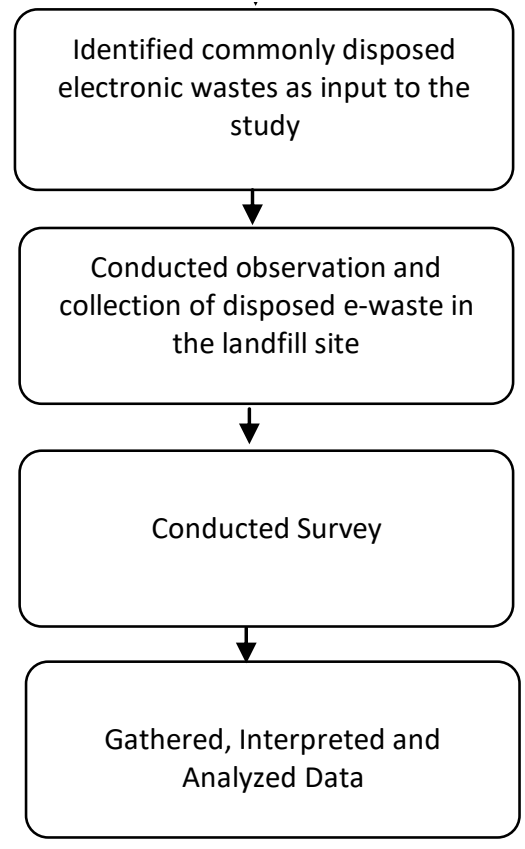

Figure 1. The Research Process Flow Chart

\section{Results and Discussion}

http://dx.doi.org/10.22135/sje.2021.6.1.8-12 
This section presents the data gathered from the answers of the respondents on their disposal practices and problems encountered. Table 1 displays the frequency and ranking of the disposal management practices of unserviceable electronic resources in Calbayog City.

Table 1: Frequency and Ranking on the Disposal Management Practices of Unserviceable Electronic Resources in Calbayog City

\begin{tabular}{lcccccc}
\hline \multirow{2}{*}{$\begin{array}{c}\text { Disposal Management } \\
\text { Practices }\end{array}$} & \multicolumn{2}{c}{ Establishments } & \multicolumn{2}{c}{ Household } & \multicolumn{2}{c}{ Overall } \\
\cline { 2 - 7 } & Frequency & Rank & Frequency & Rank & Frequency & Rank \\
\hline $\begin{array}{l}\text { Repair to extend their life } \\
\text { span }\end{array}$ & 89 & 1 & 104 & 1 & 193 & 1 \\
\hline Reuse components or parts & 86 & 2 & 100 & 2 & 186 & 2 \\
\hline $\begin{array}{l}\text { Recycle components for } \\
\text { material recovery }\end{array}$ & 80 & 3 & 92 & 4 & 172 & 3 \\
\hline $\begin{array}{l}\text { Resell for additional } \\
\text { income }\end{array}$ & 75 & 5 & 94 & 3 & 169 & 4 \\
\hline Dispose to garbage bins & 76 & 4 & 76 & 5.5 & 152 & 5 \\
\hline $\begin{array}{l}\text { Transport to an authorized } \\
\text { waste handler }\end{array}$ & 72 & 6 & 76 & 5.5 & 148 & 6 \\
\hline $\begin{array}{l}\text { Donate to be used for other } \\
\text { purposes }\end{array}$ & 63 & 7 & 68 & 7 & 131 & 7 \\
\hline Keep in a store room & 55 & 8 & 47 & 9 & 102 & 8 \\
\hline Bury in the backyard & 41 & 9 & 52 & 8 & 93 & 9 \\
\hline Burn or incinerate & 30 & 10 & 26 & 10 & 56 & 10 \\
\hline
\end{tabular}

As shown in Table 1, the top five disposal management practices were the following: repair to extend their lifespan, reuse components or parts, recycle components for material recover, resell for additional income, and dispose to garbage bins. The two groups of respondents are one of their responses to the top five disposal management practices. These results imply that the respondents from households and establishments have similar practices observed on the disposal of electronic wastes. They all observe the basic waste disposal management practices, the Reuse and Recycle. The respondents also practice the Reduce waste disposal management practice as evidenced in the reselling and repairing of their unserviceable electronic resources. These finding sustains the result of the study of Sivaramanan [7] wherein the author discussed that the safest method of disposal of electronic waste is recycling the materials and reusing them.

Table 2: Frequency and Ranking on the Problems Encountered in the Disposal Management of Electronic Waste Resources in Calbayog City

\begin{tabular}{lcccccc}
\hline \multirow{2}{*}{ Problems Encountered } & \multicolumn{2}{c}{ Establishments } & \multicolumn{2}{c}{ Household } & \multicolumn{2}{c}{ Overall } \\
\cline { 2 - 7 } & Frequency & Rank & Frequency & Rank & Frequency & Rank \\
\hline $\begin{array}{l}\text { Lack of disposal facilities } \\
\text { for e-wastes }\end{array}$ & 86 & 1 & 98 & 1 & 184 & 1 \\
\hline $\begin{array}{l}\text { Lack of public awareness } \\
\text { on its potential risks to the } \\
\text { environment and human } \\
\text { health }\end{array}$ & 70 & 3 & 83 & 2 & 153 & 2 \\
\hline $\begin{array}{l}\text { Lack of proper recycling } \\
\text { activities for e-waste }\end{array}$ & 75 & 2 & 74 & 4 & 149 & 3 \\
\hline $\begin{array}{l}\text { Lack of infrastructure for } \\
\text { formal collection and } \\
\text { recycling of e-waste }\end{array}$ & 69 & 4 & 66 & 7.5 & 135 & 4 \\
\hline $\begin{array}{l}\text { No establishments buying } \\
\text { disposed electronic wastes }\end{array}$ & 62 & 5 & 67 & 6 & 129 & 5 \\
\hline $\begin{array}{l}\text { Improper segregation of } \\
\text { wastes }\end{array}$ & 53 & 7 & 75 & 3 & 128 & 6 \\
\hline $\begin{array}{l}\text { No specific policy on } \\
\text { e-waste management }\end{array}$ & 54 & 6 & 73 & 5 & 127 & 7 \\
\hline $\begin{array}{l}\text { No specific program by } \\
\text { the local government to } \\
\text { help properly dispose of e- } \\
\text { waste }\end{array}$ & 52 & 8 & 64 & 9 & 116 & 8 \\
\hline $\begin{array}{l}\text { Illegal dumping of } \\
\text { e-waste }\end{array}$ & 42 & 10 & 66 & 7.5 & 108 & 9 \\
\hline $\begin{array}{l}\text { Inadequate cooperation on } \\
\text { e-waste disposal among } \\
\text { the stakeholders }\end{array}$ & 41 & 11 & 47 & 10 & 88 & 10 \\
\hline $\begin{array}{l}\text { Lack of personnel who } \\
\text { man garbage collection }\end{array}$ & 43 & 9 & 40 & 12 & 83 & 11 \\
\hline $\begin{array}{l}\text { Irregular schedule of } \\
\text { garbage collection by } \\
\text { garbage collectors }\end{array}$ & 32 & 12 & 43 & 11 & 75 & 12 \\
\hline
\end{tabular}

Table 2 presents the results of the survey on problems encountered by the respondents in the disposal of electronic wastes. The results showed the top five (5) problems encountered. These are: lack of disposal facilities for e-wastes; lack of public awareness on its potential risks to the environment and human health; lack of proper recycling activities for e-waste; lack of infrastructure for formal collection and recycling of e-waste; and no establishments buying disposed electronic wastes. The data also revealed that both of the respondents had commonly viewed the item 'Lack of disposal facilities for e-wastes' being the most felt problem. The results on the problems encountered in the disposal management of electronic waste resources is supported by the findings of Bhat and Patil[8] when the authors found that the e-waste collection facility is not available $61 \%$ among households of Pune City. Likewise, the study of Katti, et.al.[9] revealed that $61 \%$ of people in Metro Cities of India are not aware of impact of proper disposal of unused electronic and electrical equipment (EEE). Therefore, lack of disposal facilities and lack of public awareness on potential risks to the environment and human health are a common problem. This implies that the Local Government needs to address such issue by coming up with more disposal facilities intended for electronic wastes. Also, the lack of disposal facilities for e- 
wastes does not support the implementation of the Republic Act (RA) 6969, known as the Toxic Substances and Hazardous and Nuclear Waste Control of 1990.

However, the results showed that the respondents differ in their responses to the next four problems. With these differences, each of the group of respondents could have different experiences and needs. For instance, on lack of public awareness on its potential risks to the environment and human health, households felt it more like a problem since they need to be aware of the potential risks of electronic wastes to the environment and human health. Whereas, the establishments are already informed about potentials risks of electronic wastes since they are required to comply with mandates concerning environment protection and preservation. On the lack of proper recycling activities for e-waste, the establishments felt it more like a problem since they have more electronic wastes to dispose of as compared to households. With this, the establishments consequently considered the lack of infrastructure for formal collection and recycling of e-waste a problem considering the volume of their electronic wastes to be disposed of. On the problem of no establishments buying disposed electronic wastes, the households treated it more of a problem due to the absence of scrap buyers of electronic wastes, unlike the establishments, which are primarily identified as the source of electronic wastes to be collected and sold to scrap buyers. With the differences identified on the problems encountered, this implies that there is an unsustainable way of disposal of electronic wastes

\section{Conclusion}

The study showed that the establishments and households in Calbayog City practice the mandated activities of disposing of the unserviceable electronic resources. As evident in the results, the establishments and households practice the 3 Rs of waste management. However, these practices are hindered by some problems so that the establishments and households had difficulty to sustain. Among these problems, the most noted was the lack of disposal facilities for ewaste. Therefore, there is a need to strategize solution that will address the most imminent problem identified. The local government is in position to play a crucial counterpart in coming up a disposal facility that will manage electronic wastes especially that there is a lack of disposal facility for electronic wastes as found in the study (f=184).

Consistent with the findings of this study, the local government may use the results of the study as basis or inputs to enhancing the government programs for waste disposal, particularly on electronic wastes. The public may be educated on the potential risks of electronic wastes and proper waste disposal management. Finally, a further study may be conducted to explore more on solutions to problems in e-waste disposal, environment protection, human health, and other issues.

\section{Acknowledgement}

The authors acknowledged Northwest Samar State University for funding this research project.

\section{References}

[1] D. S. Polaiah, "Impact of Technology on Environment", International Journal of Engineering Science Invention (IJESI), PP. 53-55, retrieved March. 19, 2020,[Online]. Available:http://www.ijesi.org/papers/Conf.1 802(ICMEEP)/Vol-5/12.\%2053-55.pdf

[2] K. A. Junaidah, "Electrical and Electronic Waste Management Practice by households in Shah Alam, Selangor, Malaysia." International Journal of Environmental Sciences,vol.1, no.2,pp.132145, retrieved:No vember,2010.[Online].Available:http://www .ipublishing.co.in/jesvol1no12010/EIJES1013 .pdf

[3] Yale Environment 360 "Volume Of E-Waste" retrieved November 7, 2014,[Online]. Available:http://e360.yale.edu/digest/volume _of_ewaste_projected_to_soar_by_2017_st udy_says/4027/ 
[4] Integrated Waste Management Board. "Best Management Practices for Electronic Waste". retrieved: July 31, 2013,[Online]. Available:http://c0133311.cdn.cloudfiles.rac kspacecloud.com/Guide\%20\%20EWaste\%20 Best\%20Management\%20Practices\%20SF.p df.

[5] S. Priyadharshini, and T.Meenambal "A survey on Electronic waste management in Coimbatore", International Journal of Engineering Science and Technology, vol.3 no.3, pp.2099-2104; retrieved: July 31, 2013,[Online].Available:http://www.ijest.inf o/docs/IJEST11-03-03-114.pdf.

[6] G.L.Peralta, and P.M.Fontanos, "E-waste issues and measures in the Philippines" Journal Mater Cycles Waste Management, vol.8, pp.34-39; retrieved: July 31, 2013,[Online].Available:http://www.environ mentalexpert.com/Files\%5C6063\%5Carticle s\%5C $9020 \% 5 \mathrm{C} 1 . \mathrm{pdf}$.

[7] S. Sivaramanan, "E-Waste Management, Disposal and Its Impacts on the Environment", Universal Journal of Environmental Research and Technology, vol.3, no.5, pp.531-537, 2013,[Online].Available:https://www.researc hgate.net/publication/267217916_EWaste_M anagement_Disposal_and_Its_Impacts_on_th e_Environment.

[8] V.P.Bhat, and Y. Patil "E-waste Consciousness and Disposal Practices among Residents of Pune City", in Procedia-Social and Behavioral Sciences 133,pp.491498.retrievedMay,2014.[Online].Available:ht tps://www.researchgate.net/publication/2740 28869_Ewaste_Consciousness_and_Disposal _Practices_among_Residents_of_Pune_City.

[9] A. Katti., M. B. Shinde, and N. V. Patil., "Nursing Students Knowledge, Attitude, and Practice Towards E-waste Management", Journal of Critical Reviews, vol. 7, no. 7, 2020.[Online].Available:http://www.jcrevie $\mathrm{w} . \mathrm{com} / ? \mathrm{mno}=105518$. 